\title{
Investigation of the Potential Association between Clustered Regularly Interspersed Short Palindromic Repeats (CRISPR) and Antibiotic Resistance Pattern of Bacterial Strains Isolated from Medical Waste and Environmental Water
}

\author{
Md. Shahariar Alam, Sajib Chakraborty, Taibur Rahman, Md. Ismail Hosen, Anik Paul, \\ A. K. M. Mahbub Hasan, M. Anwar Hossain*
}

Department of Biochemistry and Molecular Biology, University of Dhaka, Dhaka, Bangladesh

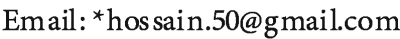

How to cite this paper: Alam, Md.S., Chakraborty, S., Rahman, T., Hosen, Md.I., Paul, A., Mahbub Hasan, A.K.M. and Hossain, M.A. (2018) Investigation of the Potential Association between Clustered Regularly Interspersed Short Palindromic Repeats (CRISPR) and Antibiotic Resistance Pattern of Bacterial Strains Isolated from Medical Waste and Environmental Water. Open Journal of Medical Microbiology, 8 , 13-25.

https://doi.org/10.4236/ojmm.2018.82002

Received: February 25, 2018

Accepted: June 26, 2018

Published: June 29, 2018

Copyright $\odot 2018$ by authors and Scientific Research Publishing Inc. This work is licensed under the Creative Commons Attribution International License (CC BY 4.0)

http://creativecommons.org/licenses/by/4.0/

\begin{abstract}
Enterobacteriaceae are important human pathogens that cause many food and waterborne illness. Rapid emergence of multi-drug resistant bacteria in Bangladesh has become a serious problem. Phage-host interaction is now considered as the major driving force for the conversion of non-pathogenic bacteria to pathogenic ones. Evolution of highly pathogenic and antibiotic resistant bacteria largely depends upon the horizontal gene transfer by means of plasmid, megaplasmid and bacteriophages. Conversely, bacteria may acquire a novel defence mechanism called CRISPR (Clustered regularly interspersed short palindromic repeats) that can restrict horizontal transfer of plasmids and bacteriophages to limit the spread of antibiotic resistance genes among bacterial species. In this study, twenty bacterial strains were isolated from water of different medical waste and Buriganga river. Therefore, CRISPR locus was investigated following various biochemical and molecular analysis of those bacterial isolates. Identification of the bacterial isolates was conducted by Polymerase Chain Reaction (PCR) based assay of 16S rDNA extracted from those isolated strains. Results indicated that most strains were identified as Proteus mirabilis and Citrobacter freundii which mainly cause septicemia, and pneumonia in human. Thereafter, antibiogram of these strains was performed by using 11 different antibiotic discs where bacterial isolates from medical drainage system showed more resistant to antibiotics than the river
\end{abstract}


water. In this study, CRISPR locus was also investigated within the genome of the isolated bacterial stains but unexpectedly, we did not find any CRISPR locus in their genome. In conclusion, we confirm that multi-drug resistant bacterial strains are devoid of CRISPR locus suggesting a possible negative association between CRISPR locus and antibiotic resistance. Further studies to pinpoint are required to elucidate the underlying mechanism of the association between CRISPR and antibiotic resistance in these isolated strains.

\section{Keywords}

Enterobacteriaceae, Antibiotic Resistance, Proteus Mirabilis, Citrobacter freundii, CRISPR-Cas

\section{Introduction}

Prevalence of infectious diseases is very high in developing countries like Bangladesh. This might be due to lack of awareness, proper hygiene, poverty and change of climate. Moreover, illiteracy and lack of knowledge add an additional threat for spreading the causative agent of these diseases. Transmission of the diseases by food and water is a matter of great concern in Bangladesh. Many pathogenic bacteria of Enterobacteriaceae family, for instance Proteus, Citrobacter, cause various infectious diseases among the people which are mainly transmitted through contaminated food and water. Proteus are important opportunistic pathogens that cause urinary tract and septic infections in human. Hospital Acquired Infection (HAI) is also caused by these bacteria [1] and they generally found in animals, birds, reptiles, soil sewage, polluted water and human intestine. Previous study showed that approximately one-fourth populations of the world carry intestinal Proteus [2]. On the other hand, Citrobacter causes neonatal sepsis, meningitis, necrotizing encephalitis and brain abscesses [3]. Furthermore, Citrobacter can also cause a wide spectrum of infections, such as infections in the urinary tract, respiratory tract, wounds, bone, peritoneum, endocardium, meninges, and bloodstream in aged ( $\geq 65$ years) individuals or in immunocompromised patients. Therefore, the rate mortality by Citrobacter infections is very high from $2.0 \%$ to $17.7 \%$ [3] [4].

To treat bacterial infections, antibiotics are commonly used where they clear the infection by either killing the bacteria or inhibiting their growth [5] [6]. The uses of antibiotics have become very frequent in our country and are not monitored carefully. Due to lack of knowledge people sometimes do not follow the dose of antibiotic properly. As a result, the emergence of antibiotic resistance has become a common and detrimental phenomenon in Bangladesh. In addition, antibiotic resistance bacteria spread to the environment because of mismanagement of patients in hospital [7] [8]. World Health Organization (WHO) defines antibiotic resistance as a phenomenon of microorganisms to become resistant to an antimicrobial drug/antibiotic that was once able to treat an infection by that 
microorganism [9]. In this case microorganisms develop a mechanism so that the antibiotic can no longer destroy the bacterial growth.

Antibiotic resistance develops in a bacterial strain by acquired modification or changing in its genetic materials [10]. The mechanism by which genes for antibiotic resistance are transmitted among the bacterial strains is called Horizontal gene transfer (HGT) [11] [12]. Horizontal gene transfer occurred in bacteria by transformation, transduction and conjugation [11]. Particularly transformation play important role for spread of antibiotic resistance [13]. Recently, a novel mechanism found in bacteria that potentially limit the spread of antibiotic resistance by preventing HGT is known as Cluster Regularly Interspaced Short Palindromic Repeats (CRISPR) [14] [15]. CRISPR represents a family of DNA repeats, found in the genome of almost all archaea and many bacteria [16] [17]. It provides acquired immunity in the bacteria against extra-chromosomal DNA. This distinct array of short repeated sequence is interspaced with unique sequence called spacer [14] [15] [17] [18].

In this study, wastewater from medical drainage system and water from Burigonga River was collected for isolation of Enterobacteriaceae. Biochemical and molecular characterization of the isolated strains was carried out to identify the isolated bacterial strains. Here, $16 \mathrm{~S}$ rRNA gene was considered as the gold standard in identifying bacterial strains by Polymerase chain reaction (PCR). Thereafter, antibiotic resistance profiling of the isolated bacterial strains was performed. To this end, CRISPR loci were investigated in those bacterial strains and were characterize using in silico approach.

\section{Methods and Materials}

\subsection{Sample Collection and Isolation of Single Colony}

Water samples were collected in a sterile falcon tube from hospital drainage system and Buriganga river. In total ten and twenty water samples were collected from hospital drainage and Buriganga river respectively. Collected samples were transferred aseptically to the laboratory and processed by diluting four times with distilled water and then stored in a refrigerator at $4^{\circ} \mathrm{C}$. Samples were grown in selective Salmonella-Shigella-agar (SS agar) media. After overnight incubation, 20 bacterial colonies were selected for further experimental analysis. All samples were collected in the period of 2015 to 2016.

\subsection{Identification of Bacterial Isolates}

Characterization of the bacterial isolates was carried out using biochemical tests for instance Motility Test, Catalase Test, Gelatin Hydrolysis Test, Indole Test, Urease Test, Triple Sugar Iron Agar Test. All the tests were performed according to the protocol of ASM Microbe Library (http://www.microbelibrary.org). And $16 \mathrm{~S}$ rRNA gene based polymerase chain reaction (PCR) was performed using 16S rRNA gene primes for identification of the isolated bacteria (after sequencing the PCR product). 


\begin{tabular}{cc}
\hline Primer & Sequence \\
\hline Forward & 5'-GAGTTTGATCCTGGCTCA-3' \\
Reverse & 5'-ACGGCTAACTTGTTACGA CT-3' \\
\hline
\end{tabular}

\subsection{Antibiotic Susceptibility Test}

The Kirby-Bauer disc diffusion test was carried out with the isolated bacteria to determine the sensitivity or resistance towards various commonly used antibiotics $(n=11)$. The concentration of antibiotics those were used in this study are Ampicillin (AMP) $25 \mu \mathrm{g}$; Nalidixic acid (NA) $30 \mu \mathrm{g}$; Tetracycline (TE) $30 \mu \mathrm{g}$; Kanamycin (K) $30 \mu \mathrm{g}$; Doxycycline (DO) $30 \mu \mathrm{g}$; Streptomycin (S) $10 \mu \mathrm{g}$; Ciprofloxacin (CIP) $5 \mu \mathrm{g}$; Penicillin (P) $10 \mu \mathrm{g}$; Cotrimoxazole (COT) $25 \mu \mathrm{g}$; Gentamicin (GEN) $10 \mu \mathrm{g} \&$ Chloramphenicol (C) $30 \mu \mathrm{g}$. Clustering of bacterial strains based on the antibiotic susceptibility pattern was performed by using K-means clustering algorithm.

\subsection{In Silico Study}

In Silico analysis is an important medium for initial identification and characterization of bacterial strain. In this analysis, different Bioinformatic tools were utilized to identify the isolated bacterial strain and to study CRISPR-cas system of isolated Enterobacteriacaea.

\subsection{Basic Local Alignment Search Tool (BLAST)}

Basic Local Alignment Search Tool (BLAST) is an online program of National Center for Biotechnology Information (NCBI)

(https://blast.ncbi.nlm.nih.gov/Blast.cgi). To identify the bacterial isolates and other similar organism having similar sequence BLAST program was used.

\subsection{CRISPRs Web Server}

This site acts as a gateway to publicly accessible CRISPRs database and software (http://crispr.i2bc.paris-saclay.fr/). It enables the easy detection of CRISPRs in locally-produced data and consultation of CRISPRs present in the database. This web site is the product of an original work by Ibtissem Grissa ( $\mathrm{PhD}$ thesis Paris University), improved by Christine Drevet, and presently developed by David Couvin. CRISPR locus information was derived from this database.

\subsection{Molecular Evolutionary Genetics Analysis (MEGA)}

Molecular Evolutionary Genetics Analysis (MEGA) is computer software for conducting statistical analysis of molecular evolution and for constructing phylogenetic trees (Tamura et al., 2013). It includes many sophisticated methods and tools for phylogenomics and phylomedicine. MEGA was used for the comparative analysis of molecular sequence data was used for reconstructing the evolutionary histories of species and inferring the nature and extent of selective forces shaping the evolution of genes and species. 


\section{Results \& Discussions}

Enterobacteriaceae are a group of bacteria that can cause many infectious diseases in human world-wide. To treat these bacterial infections, antibiotics are the preferred choice because antibiotics can suppress the growth and/or can kill the bacteria effectively. But misuses of antibiotics in developing countries like Bangladesh help the bacteria to develop resistance against multiple drugs. In addition, bacteria try to develop self defense mechanism named CRISPR-cas against the antibiotics through acquiring resistance genes. Therefore, spreading of the antibiotic resistance is a new thread for us. With the aim of elucidating the CRISPR pathway in bacterial spp. we designed a detailed study plan to investigate the active CRISPR locus and their role in blocking phage/plasmid infection by both bioinformatics and experimental approach. In this study, antibiotic resistance pattern in bacteria (Enterobacteriaces) isolated from the collected samples were observed along with their identification. Characterization of CRISPR in these bacteria was also done as CRISPR cas system provide bacteria a potential immunity mechanism in bacteria [14].

\subsection{Biochemical Identification of Bacterial Isolates}

In total seven and thirteen bacterial strains were isolated from Buriganga river and medical waste water respectively. The identification pathogenic bacterial strains in the Buriganga river points towards the possibility of contaminating their river water medical sewage containing pathogenic bacterial strains from nearby hospital. Because hospitals always deal with numerous patients with infectious disease, so the drainage system of hospitals might be contaminated with pathogens and could be a good source for antibiotic resistant bacteria. Another site for sample collection was Buriganga river, because this river water is contaminated with the sewerage water dumped by numerous river side industries and hospitals. After isolating bacteria through culturing in Salmonella Shigella (SS) agar media, various biochemical tests were performed to identify the bacterial isolates. Results showed most of the bacterial isolates were positive for the test of motility $(\mathrm{N}=13)$, catalase $(\mathrm{N}=20)$, urease production $(\mathrm{N}=18)$, and capacity to gelatin hydrolysis $(\mathrm{N}=12)$ but all were negative for gram stain and indole production.

\subsection{Antibiotic Susceptibility Test of Bacterial Isolates}

Antibiogram of the isolated bacteria were shown in a HeatMap (Figure 1) where the strains were divided into two Groups A \& B. The strains of Group A showed less resistance against various antibiotics than Group B. But Strain-5 was a hospital isolate which showed most resistant against the used antibiotics, therefore this strain didn't include into those two groups. The bacterial strains of Group A except strain 13 and 14 were isolated from Buriganga river whereas Group B strains were isolated from hospital drainage system. Results indicated that multi-drug resistance bacteria were more prevalent in hospital drainage system as 


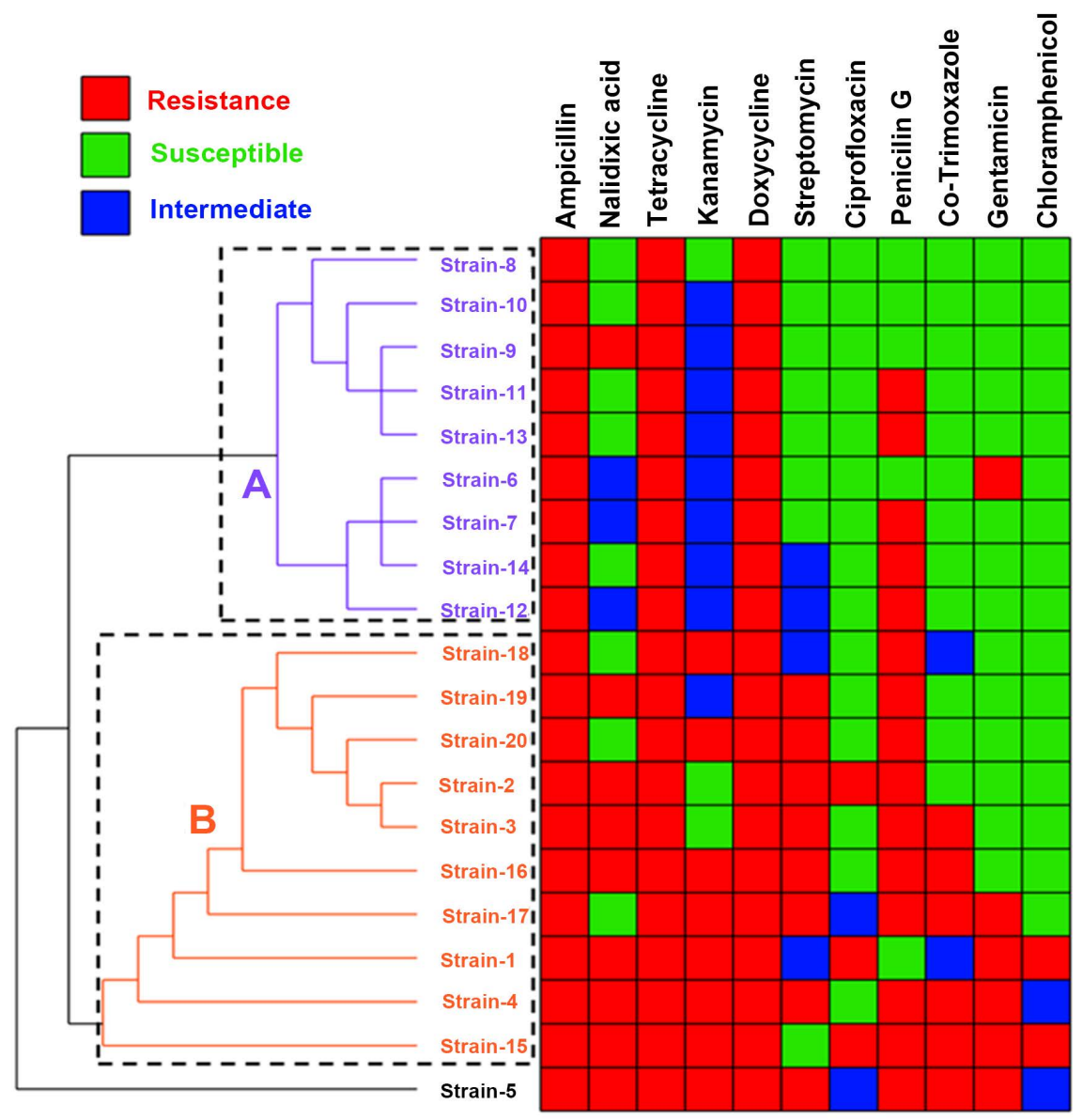

Figure 1. Antibiotic susceptibility is shown here by Heat map. Rows represent antibiotics and columns represent bacterial strains; where red blocks indicate resistance, green blocks indicate antibiotic susceptibility and blue blocks indicate intermediate action of the antibiotics. According antibiotic susceptibility strains are divided into 2 groups Group A and Group B. The strains of Group A showed less resistance against the antibiotics than Group B. Strain-5 didn't belong to any groups as no antibiotic shows resistance against Strain-5.

compared to Buriganga river. Previously it was found that lactose fermenting Enterobacteriaceae isolated from clinical samples were more resistant to antibiotic than environmentally isolated lactose fermenting Enterobacteriaceae [19]. It is possible that the bacteria isolated from hospital drainage system may originate from infected patient of those hospitals. And these bacteria were previously exposed to antibiotics during treatment. Therefore, it is not unlikely that due to prior exposure to antibiotics these bacterial strains developed antibiotics resistance [20]. Whereas the bacterial strains isolated from Buriganga river may have remained unexposed to antibiotics and show less antibiotic resistance.

\subsection{Bacterial Resistance Pattern to Multiple Antibiotics}

The next question was to determine the percentages of bacterial strains which showed resistance to multiple antibiotics. Therefore, a pie chart was created that confirmed $35 \%$ of bacterial strains were resistant to four different antibiotics. 
The percentage of resistance against multiple antibiotics among the isolated bacterial strains is presented in Pie chart (Figure 2). All the bacterial isolates show multiple resistance patterns and one strain found to be resistant against ten among the eleven antibiotics.

\subsection{S rRNA Gene Sequence Based Identification of Isolated Bacterial Strains}

The Basic Local Alignment Search Tool (BLAST) was used to identify the unknown query sequence (16S rRNA gene) that match best with the known sequence present in NCBI databases. The sequence of $16 \mathrm{~S}$ rRNA gene of Strain 1 to Strain 12 bacteria nucleotide were blasted using online blast tool in National Center for Biotechnology Information (NCBI; Altschul et al., 1997; http://www.ncbi.nlm.nih.gov/blast). The 16S rRNA gene sequences of 12 bacterial strains have been deposited in the GenBank data base and accession numbers have been obtained. The name alone with the accession number obtained from the BLAST results of bacterial isolates are given in Table 1. Their source and name of susceptible antibiotics are also given.

\subsection{Molecular Identification of Bacterial Isolates}

For species identification of bacteria molecular approach is needed. 16S rRNA gene is considered as the gold standard in identifying bacterial strains by molecular methods. 16S rRNA gene sequence is the universal genetic marker for identification of bacterial strains as all it is most common housekeeping gene in all bacteria [21] [22]. Genomic DNA of the bacterial isolates were extracted using alkaline lysis buffer. Identification of the bacterial isolates were conducted by Polymerase chain reaction (PCR) based assay of $16 \mathrm{~S}$ rRNA gene and DNA



Figure 2. The Pie chart shows the percentage of resistance against multiple antibiotics among the isolated bacterial strains. At least the isolated strains showed triple resistance and at most 1 strain shows resistance against ten antibiotics. 
Table 1. Strain name obtained from the BLAST result, their source \& name of susceptible antibiotics.

\begin{tabular}{|c|c|c|c|c|}
\hline Sample no. & Organism (strain) & Accession no. & Source & $\begin{array}{l}\text { Susceptible } \\
\text { antibiotics }\end{array}$ \\
\hline Strain 1 & $\begin{array}{c}\text { Proteus mirabilis strain } \\
\text { AR_0059 }\end{array}$ & СР020052.1 & $\begin{array}{l}\text { DMC drainage } \\
\text { system }\end{array}$ & $\mathrm{P}$ \\
\hline Strain 2 & $\begin{array}{c}\text { Proteus mirabilis strain } \\
\text { BPLM1 }\end{array}$ & KX156215.1 & $\begin{array}{l}\text { DMC drainage } \\
\text { system }\end{array}$ & K, COT, GEN, C \\
\hline Strain 3 & $\begin{array}{c}\text { Proteus mirabilis strain } \\
\text { R_0059 }\end{array}$ & СР020052.1 & $\begin{array}{l}\text { DMC drainage } \\
\text { system }\end{array}$ & K, CIP, GEN, C \\
\hline Strain 4 & $\begin{array}{c}\text { Proteus mirabilis strain } \\
\text { SFSA68 }\end{array}$ & KU744865.1 & $\begin{array}{l}\text { DMC drainage } \\
\text { system }\end{array}$ & $\mathrm{C}$ \\
\hline Strain 5 & $\begin{array}{c}\text { Proteus mirabilis strain } \\
\text { VJ02 }\end{array}$ & KX781272 1 & $\begin{array}{l}\text { DMC drainage } \\
\text { system }\end{array}$ & \\
\hline Strain 6 & $\begin{array}{c}\text { Proteus mirabilis strain } \\
\text { PAS, isolate } 3\end{array}$ & LT745977.1 & $\begin{array}{l}\text { Buriganga river } \\
\text { water }\end{array}$ & S, CIP, P, COT, C \\
\hline Strain 7 & $\begin{array}{c}\text { Proteus sp. strain KR } \\
249\end{array}$ & KY944568.1 & $\begin{array}{l}\text { Buriganga river } \\
\text { water }\end{array}$ & $\begin{array}{c}\mathrm{S}, \mathrm{CIP}, \mathrm{COT}, \mathrm{GEN}, \\
\mathrm{C}\end{array}$ \\
\hline Strain 8 & $\begin{array}{l}\text { Citrobacter freundii } \\
\text { strain M5 }\end{array}$ & KT792726.1 & $\begin{array}{l}\text { Buriganga river } \\
\text { water }\end{array}$ & $\begin{array}{l}\text { NA, K, S, CIP, P, } \\
\text { COT, GEN, C }\end{array}$ \\
\hline Strain 9 & $\begin{array}{l}\text { Citrobacter freundii } \\
\text { strain RP-VR } 3014\end{array}$ & KC835089.1 & $\begin{array}{l}\text { Buriganga river } \\
\text { water }\end{array}$ & $\begin{array}{l}\text { S, CIP, P, COT, } \\
\text { GEN, C }\end{array}$ \\
\hline Strain 10 & $\begin{array}{c}\text { Proteus mirabilis strain } \\
\text { AR_0059 }\end{array}$ & СР020052.1 & $\begin{array}{l}\text { Buriganga river } \\
\text { water }\end{array}$ & $\begin{array}{l}\text { NA, S, CIP, P, } \\
\text { COT, GEN, C }\end{array}$ \\
\hline Strain 11 & $\begin{array}{c}\text { Proteus mirabilis strain } \\
\text { SFSA63 }\end{array}$ & KU744860.1 & $\begin{array}{l}\text { Buriganga river } \\
\text { water }\end{array}$ & $\begin{array}{c}\text { NA, S, CIP, COT, } \\
\text { GEN, C }\end{array}$ \\
\hline Strain 12 & $\begin{array}{l}\text { Citrobacter freundii } \\
\text { strain GX12 }\end{array}$ & KU937375.1 & $\begin{array}{l}\text { Buriganga river } \\
\text { water }\end{array}$ & CIP, COT, GEN, C \\
\hline
\end{tabular}

${ }^{*} \mathrm{DMC}=$ Dhaka Medical Collage; $\mathrm{AMP}=$ Ampicillin; $\mathrm{NA}=$ Nalidixic acid; $\mathrm{TE}=$ Tetracycline; $\mathrm{K}=$ Kanamycin; DO = Doxycycline; $\mathrm{S}=$ Streptomycin; $\mathrm{CIP}=$ Ciprofloxacine; $\mathrm{P}=$ Penicillin; $\mathrm{COT}=$ Cotrimoxazole; GEN $=$ Gentamicin; $\mathrm{C}=$ Chloramphenicol.

extracted from the isolated strains were amplified by using 2 universal primers 27F and 1492R (Figure 3). 1500 base pair [21] sequence of 16S rRNA gene was sequenced by Sanger sequencing method after performing PCR. Sequencing of first 12 isolated bacterial strains (Strain 1 to Strain 12) was done. Molecular identification reveals the isolated bacteria belongs to Proteus \& Citrobacter bacterial strain. These bacteria are more prevalent in the environmental samples as they are mostly found in the human fecal excretion [23]. And samples for this study were collected from drainage system and river. Highly similar nonrodent nucleotide BLAST results of the sequences show that Strain 8, $9 \& 12$ includes Citrobacter freundii bacterial species and Strain 1, 2, 3, 4, 5, 6, 7, 10 \& 11 includes Proteus mirabilis bacterial species. Homology between the bacterial isolates were found when a phylogenetic tree was constructed using the 16S rRNA gene sequences. This suggests Citrobacter freundii and Proteus mirabilis poses similar type of $16 \mathrm{~S}$ rRNA gene.

\subsection{Phylogenetic Tree of 16S rDNA Bacterial Isolates}

A phylogenetic tree was constructed using MEGA6 software. Twelve sequences of $16 \mathrm{~S}$ rDNA from the sequencing result were used to construct phylogenetic 


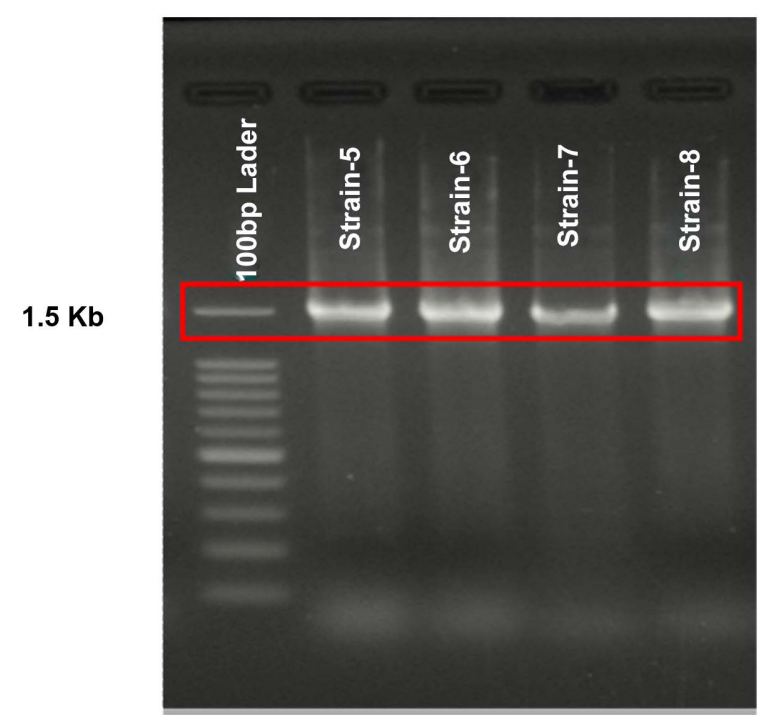

Figure 3. Gel electrophoresis of the PCR product of DNA for $16 \mathrm{~S}$ rDNA. (Lane1: Ladder, Lane2: Strain-5, Lane3: Strain-6, Lane4: Strain-7, Lane5: Strain-8). Band found at $1.5 \mathrm{~Kb}$.

tree. Phylogenetic relations among the bacterial strains are shown in the constructed phylogenetic tree (Figure 4).

\subsection{Identification CRISPR Locus in Bacterial Isolates}

To identify CRISPR locus in the bacterial isolates (Proteus \& Cirobacter), PCR was performed using two CRISPR locus primers CRISPR-1, and CRISPR-2. Results confirmed that there was no CRISPR locus present in the isolated bacterial strains after performing PCR followed by agarose gel electrophoresis (Figure 5). As Most of the bacterial isolates showed antibiotic resistance, therefore the lack of CRISPR locus may facilitate the acquisition of antibiotic resistance cassette in these bacterial strains. On the contrary, we cannot rule out the possibility that the bacteria might have atypical CRISPR locus that didn't match with our universal primers sequence or they may have CRISPR locus not in the genomic DNA but in their plasmid.

\subsection{Bioinformatic Analysis}

Acquiring new genes are important for bacteria to become antibiotic resistance. Bacteria acquire new genes by horizontal gene transfer [12]. CRISPR-cas has recently been identified in many bacteria and archeaea as adaptive immune system that prevent acquisition of extra chromosomal genetic elements into them. So, there may be an inverse correlation between antibiotic resistance and CRISPR locus in bacteria. As CRISPR-cas system play potential role in limiting antibiotic resistance in the bacteria by preventing phage mediated horizontal gene transfer of antibiotic resistance genes in bacteria as previous studies showed that the bacteria capable of incorporating phage DNA sequence as spacers into the CRISPR loci and become resistant to that phage infection [15]. That's why a 


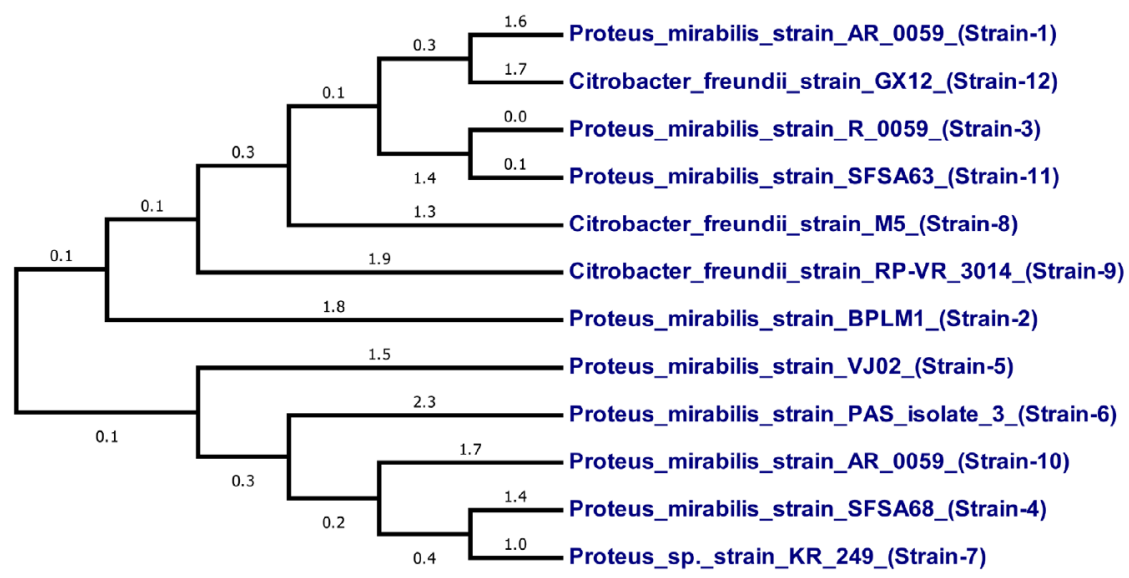

Figure 4. Phylogenetic neighbor joining tree of $16 \mathrm{~S}$ rRNA gene sequences of 12 bacterial isolates.

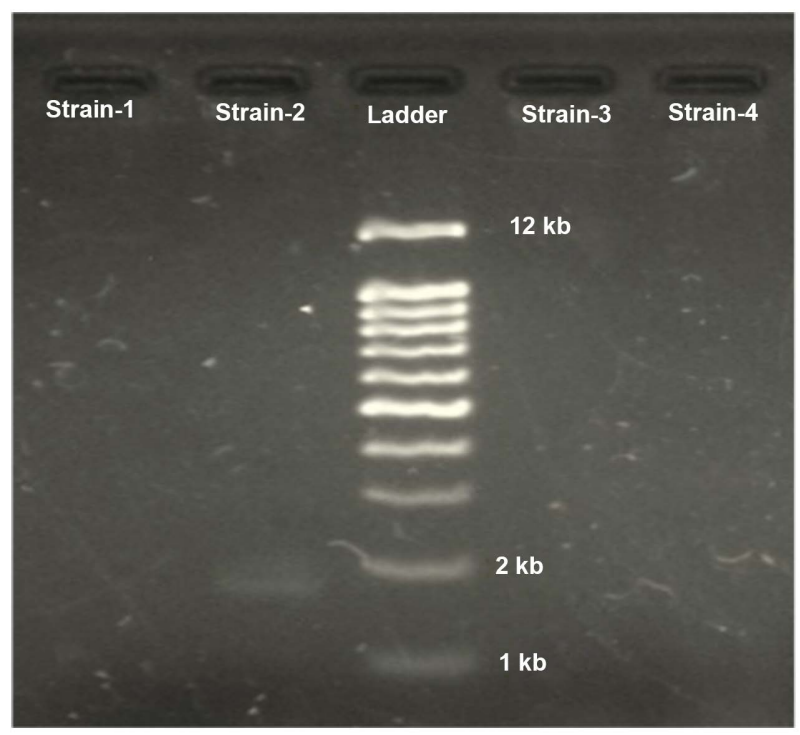

Figure 5. Gel image of PCR product obtained by using CRISPRprimer. No band found for $2.1 \mathrm{~kb}$. That indicate the bacterial isolates have no CRISPR locus in their genome. Line-2 for Strain-1; line-3 for Strain-2; line-4 for ladder; line- 5 for Strain-3 \& line- 6 for Strain- 4 .

statistical study was conducted for CRISPR locus and molecular approach was used for identification of CRISPR locus in isolated isolates bacterial.

In total genome and plasmid sequences of 14 and 7 bacterial strains from $\mathrm{Ci}$ trobacter and Proteus species respectively were searched for the presence of putative CRISPR locus. CRISPR finding tool as implemented in CRISPRdb was utilized to annotate potential CRISPR locus.

Surprisingly most of the analyzed genomes were found to be devoid of any CRISPR locus. Only two Citrobacter strains (Citrobacter koseri ATCC BAA-895 and Citrobacter rodentium ICC168) out of 14 was observed to harbor CRISPR locus (Table 2). In case of Proteus three out of five strains (Proteus mirabilis 
Table 2. Number of CRISPR positive Citrobacter and Proteus strains obtained from database.

\begin{tabular}{cc}
\hline Citrobacter strains & Number of CRISPR locus \\
\hline Citrobacter amalonaticus GCF_001558935 & 0 \\
Citrobacter amalonaticus GCF_001559075 & 0 \\
Citrobacter amalonaticus Y19 GCF & 0 \\
Citrobacter freundii CFNIH1 GCF_000648515 & 0 \\
Citrobacter freundii GCF_001022155 & 0 \\
Citrobacter freundii GCF_001022275 & 0 \\
Citrobacter freundii GCF_001281005 & 0 \\
Citrobacter freundii GCF_001702455 & 0 \\
Citrobacter freundii GCF_001718055 & 0 \\
Citrobacter freundiiGCF_001922445 & 0 \\
Citrobacter koseri ATCC BAA-895 & 1 \\
Citrobacter rodentium ICC168 & 3 \\
Citrobacter sp. FDAARGOS_156 GCF_001559235 & 0 \\
\hline
\end{tabular}

GCF_001281545, Proteus mirabilis GCF_001640985 and Proteus mirabilis GCF_002055685) were found to be positive for CRISPR locus (Table 2). Interestingly no CRISPR locus was identified in the plasmid rather all the strains harbor CRISPR locus in the chromosomal DNA. All together these results strengthen the assumption that CRISPR locus in Citrobacter and Proteus strains are of chromosomal origin and may not be present in plasmids. The low number of CRISPR locus in the Citrobacter and Proteus strains as obtained from database reinforced our hypothesis that Citrobacter and Proteus strains analyzed in the current study may well lack the active CRISPR locus all together and for this reason no CRISPR locus was identified by PCR. Therefore our results can serve as a solid platform to further in depth association study between CRISPR locus and antibiotic resistance.

\section{Conclusion}

Horizontal transfer of genes by mean of plasmid and bacteriophages has often been linked to the survival advantages of the host bacterial strains. In contrast bacterial strains are known to acquire defense mechanism that can potentially restrict the events of horizontal gene transfer. CRISPR-cas systems represent such defense mechanism by which bacteria can limit the spread of horizontally transferred genes. Balance between these two opposing factors (CRISPR-cas system and horizontal gene transfer events) largely depends on the selective pressure on the bacterial strains. Exposure to antibiotics may exert such selective pressure on the bacterial strains that may shift the balance toward the efficient 
acquisition of foreign genes required for antibiotic resistance, by losing the CRISPR-cas locus. This shift of balance may be prominent in pathogenic bacteria compared to non-pathogenic ones. The acquisition of antibiotic resistance genes not only confers the survival advantages but also enables bacteria to colonize new habitats, including the hospital in which antibiotics are frequently used to treat patients.

\section{Acknowledgements}

We are grateful to Ministry of education, Bangladesh for providing the grant for this study.

\section{Conflict of Interest}

The authors declare no conflict of interest.

\section{References}

[1] Mweu, E. and English, M. (2008) Typhoid Fever in Children in Africa. Tropical Medicine \& International Health, 13, 532-540. https://doi.org/10.1111/j.1365-3156.2008.02031.x

[2] Fàbrega, A. and Vila, J. (2013) Salmonella enterica serovar Typhimurium Skills to Succeed in the Host: Virulence and Regulation. Clinical Microbiology Reviews, 26, 308-341. https://doi.org/10.1128/CMR.00066-12

[3] Kenneth, J.R. and Ray, C.G. (2004) Spread and Control of Infection. In: Ryan, K.J., Ray, C., Ryan, K.J. and Ray, C., Eds., Sherris Medical Microbiology, McGraw-Hill, New York, 978.

[4] Crump, J.A., Luby, S.P. and Mintz, E.D. (2004) The Global Burden of Typhoid Fever. Bulletin of the World Health Organization, 82, 346-353.

[5] Giannella, R.A. (1996) Chapter 21 Salmonella. In: Baron, S., Ed., Medical Microbiology, 4th Edition, University of Texas Medical Branch at Galveston, Galveston, 1-7.

[6] Williams, R.E.O. (1993) Medical Microbiology. Journal of Clinical Pathology, 1, 556-557.

[7] Shahida, S.M., et al. (2016) Hospital Acquired Infections in Low and Middle Income Countries: Root Cause Analysis and the Development of Infection Control Practices in Bangladesh. Open Journal of Obstetrics and Gynecology, 6, 28-39. https://doi.org/10.4236/ojog.2016.61004

[8] Gurley, E.S., et al. (2010) Rates of Hospital Acquired Respiratory Illness in Bangladeshi Tertiary Care Hospitals: Results from a Low Cost Pilot Surveillance Strategy. Clinical Infectious Diseases, 50, 1084-1090. https://doi.org/10.1086/651265

[9] WHO (2016) Antimicrobial Resistance. WHO Fact Sheets.

[10] Nelson, D.L. and Cox, M.M. (2008) Lehninger Principles of Biochemistry. 5th Edition, 1-1294.

[11] Cirz, R.T., et al. (2005) Inhibition of Mutation and Combating the Evolution of Antibiotic Resistance. PLoS Biology, 3, e176. https://doi.org/10.1371/journal.pbio.0030176

[12] Gyles, C. and Boerlin, P. (2014) Horizontally Transferred Genetic Elements and Their Role in Pathogenesis of Bacterial Disease. Veterinary Pathology, 51, 328-340. https://doi.org/10.1177/0300985813511131 
[13] Furuya, E.Y. and Lowy, F.D. (2006) Antimicrobial-Resistant Bacteria in the Community Setting. Nature Reviews Microbiology, 4, 36-45. https://doi.org/10.1038/nrmicro1325

[14] Marraffini, L.A. and Sontheimer, E.J. (2008) CRISPR Interference Limits Horizontal Gene Transfer in Staphylococci by Targeting DNA. Science, 322, 1843-1845. https://doi.org/10.1126/science.1165771

[15] Sorek, R., Kunin, V. and Hugenholtz, P. (2008) CRISPR-A Widespread System That Provides Acquired Resistance against Phages in Bacteria and Archaea. Nature Reviews Microbiology, 6, 181-186. https://doi.org/10.1038/nrmicro1793

[16] Ishino, Y., Shinagawa, H., Makino, K., Amemura, M. and Nakata, A. (1987) Nucleotide Sequence of the iap Gene, Responsible for Alkaline Phosphatase Isozyme Conversion in Escherichia coli, and Identification of the Gene Product. Journal of Bacteriology, 169, 5429-5433. https://doi.org/10.1128/jb.169.12.5429-5433.1987

[17] Jansen, R., Van Embden, J.D.A., Gaastra, W. and Schouls, L.M. (2002) Identification of Genes That Are Associated with DNA Repeats in Prokaryotes. Molecular Microbiology, 43, 1565-1575. https://doi.org/10.1046/j.1365-2958.2002.02839.x

[18] Haft, D.H., Selengut, J., Mongodin, E.F. and Nelson, K.E. (2005) A Guild of 45 CRISPR-Associated (Cas) Protein Families and Multiple CRISPR/Cas Subtypes Exist in Prokaryotic Genomes. PLoS Computational Biology, 1, e60.

[19] Abdul, I., Ibrahim, J., Abdul, T. and Hameed, K. (2015) Isolation, Characterization and Antimicrobial Resistance Patterns of Lactose-Fermenter Enterobacteriaceae Isolates from Clinical and Environmental Samples. Open Journal of Medical Microbiology, 5, 169-176.

[20] Hosein, I.K., Hill, D.W., Jenkins, L.E. and Magee, J.T. (2002) Clinical Significance of the Emergence of Bacterial Resistance in the Hospital Environment. Journal of Applied Microbiology, 92, 90S-97S. https://doi.org/10.1046/j.1365-2672.92.5s1.1.x

[21] Janda, J.M. and Abbott, S.L. (2007) 16S rRNA Gene Sequencing for Bacterial Identification in the Diagnostic Laboratory: Pluses, Perils, and Pitfalls. Journal of Clinical Microbiology, 45, 2761-2764. https://doi.org/10.1128/JCM.01228-07

[22] Clarridge III, J.E. (2004) Impact of $16 S$ rRNA Gene Sequence Analysis for Identification of Bacteria on Clinical Microbiology and Infectious Diseases. Clinical Microbiology Reviews, 17, 840-862. https://doi.org/10.1128/CMR.17.4.840-862.2004

[23] Al-bassam, W.W. (2013) The Isolation and Characterization of Proteus Mirabilis from Different Clinical Samples. Journal of Biotechnology Research Center, 7, 24-30. 